\title{
Reversible cerebral vasoconstriction syndrome
}

Division of Neurology, Hospital Universitário Oswaldo Cruz, University of Pernambuco, Recife, Brazil.

Recibido el 30 de junio de 2010, aceptado el 30 de julio de 2010.

Correspondencia a:

Pedro Augusto Sampaio Rocha Filho, Rua das Creoulas, 78/103-52011-270 Recife PE - Brasil. Phone/Fax: 55-81-32313668. E-mail: pasrf@ig.com.br.

\section{ABSTRACT}

Background: Reversible cerebral vasoconstriction syndrome is characterized by thunderclap headache associated with multifocal vasoconstriction of cerebral arteries in patients without aneurysmal subarachnoid hemorrhage (SAH). The vasoconstriction reverts within three months. We report a 44-year-old man who had a thunderclap headache during sexual intercourse. A similar episode occurred at rest 36 hours later. The patient had already experienced a thunderclap headache 10 years earlier, during coitus. There were no abnormalities on examination. His brain computed tomography scan was normal and cerebrospinal fluid analysis showed no xanthochromia, $15 \mathrm{WBC} / \mathrm{mm}^{3}$ and $10 \mathrm{RBC} / \mathrm{mm}^{3}$. Lumbar puncture was repeated two days later $\left(W B C=3 / \mathrm{mm}^{3}\right.$ and $\left.R B C=43 / \mathrm{mm}^{3}\right)$. An initial digital cerebral angiography showed a diffuse segmental intracerebral vasospasm. A new angiography after 15 days was normal. He remains headache-free after twenty six months. In conclusion, patients who have thunderclap headache with normal brain CT and cerebrospinal fluid without xantochromia should be investigated for this syndrome.

(Rev Med Chile 2010; 138: 1000-1003).

Key words: Cerebral arterial diseases; Coitus; Headache; Vasospasm, intracranial.

\section{Síndrome de vasoconstricción cerebral reversible}

El síndrome de vasoconstricción cerebral reversible se caracteriza por una cefalea lancinante asociada a una vasoconstricción multifocal de las arterias cerebrales, en pacientes sin hemorragia subaracnoidea causada por aneurismas. La vasoconstricción se revierte en un plazo de tres meses. Presentamos un paciente varón de 44 años que experimentó una cefalea lancinante durante el acto sexual. Un episodio similar repitió 36 horas después, pero mientras estaba en reposo. El paciente había sufrido una cefalea lancinante durante el coito, 10 años antes. El examen físico fue normal. La tomografia cerebral estaba normal y el líquido cefalorraquídeo era claro, con 15 leucocitos y 10 eritrocitos por $\mathrm{mm}^{3}$. Una angiografia cerebral digital mostró un vasoespasmo intracerebral difuso segmentario. Una nueva angiografia, efectuada 15 días después, fue normal. El paciente está libre de cefaleas después de 26 meses de seguimiento.

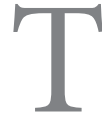
hunderclap headache $(\mathrm{TCH})$ is characterized by excruciating pain that reaches its peak intensity within less than one minute ${ }^{1}$. Its incidence is $43 / 100,000 /$ year $^{2}$. Subarachnoid hemorrhage ( $\mathrm{SAH}$ ) is responsible for 11 to $25 \%$ of the cases $^{2,3}$. Among its secondary causes, reversible cerebral vasoconstriction syndrome (RCVS) is characterized by TCH associated with multifocal vasoconstriction of cerebral arteries in patients without aneurysmal SAH. The vasoconstriction reverts within three months. The CSF is normal or close to normal ${ }^{4}$. The pathophysiology of this 
syndrome is unknown. It has been postulated that it is caused by a transitory disorder of the cerebrovascular tonus ${ }^{4,5}$.

TCH recurs in $94 \%$ of the patients with RCVS. In addition to headache, focal neurological deficits (21-63\%) or epileptic crises (3\%) may be found ${ }^{6,7}$. The complications that have been described are ischemic stroke, hemorrhagic stroke, cortical SAH, cerebral edema and arterial dissection ${ }^{4,6,8-15}$.

RCVS may occur spontaneously or, more frequently, there is a precipitating factor such as eclampsia or preeclampsia, puerperium, use of vasoconstrictor drugs, blood transfusion, tumors, hypercalcemia, porphyria, cranioencephalic traumatism, neurosurgical procedures and carotid endarterectomy ${ }^{6}$.

There are no clinical trials evaluating treatments for this syndrome. The use of vasoconstrictor drugs should be discontinued. Drugs that have been used to treat this syndrome include nimodipine, glucocorticoids and magnesium sulfate ${ }^{6,8-9,16}$.

\section{Case report}

A 44-year-old man presented $\mathrm{TCH}$ during sexual intercourse. The pain began before reaching orgasm and was located in the occipital region, bilaterally. It was associated with nausea without vomiting, photophobia or phonophobia, and lasted for five hours.

Eighteen hours after the initial headache, a second episode of $\mathrm{TCH}$ occurred while he was resting. His clinical and neurological examinations were normal.

In his past history, he reported one episode of pre-orgasmic headache similar to the above condition but of lower intensity, around ten years earlier. He was not using illegal drugs or other medications. He had been presenting tension-type headaches for 17 years.

His blood cells count, general biochemical tests, erythrocyte sedimentation rate, antinuclear factor and rheumatoid factor were normal. A cranial computed tomography (CT) scan gave normal results.

A cerebrospinal fluid (CSF) sample was obtained on the fourth day. The fluid was clear, with a leukocyte concentration of 15 cells $/ \mathrm{mm}^{3}$ that was predominantly lymphomonocytic, red blood cell concentration of 10 cells $/ \mathrm{mm}^{3}$, normal protein and glucose levels. The CSF test was repeated 48 hours later, and the fluid was found to be clear and colorless, with a leukocyte concentration of 4 cells $/ \mathrm{mm}^{3}$, red blood cell concentration of 43 cells $/ \mathrm{mm}^{3}$ and protein concentration of $72 \mathrm{mg} / \mathrm{dL}$.

Since the patient continued to have headache, a cerebral angiography was performed on the eighth day of evolution. This showed diffuse arterial spasms affecting both the anterior and the posterior circulation (Figure 1).

The patient was started on nimodipine $(60 \mathrm{mg}$ every 6 hours orally), which he used for 30 days. The headache resolved after nine days. Angiography was repeated on the fiftieth day of evolution, and was normal. There were no new headache episodes during twenty six months of follow-up.

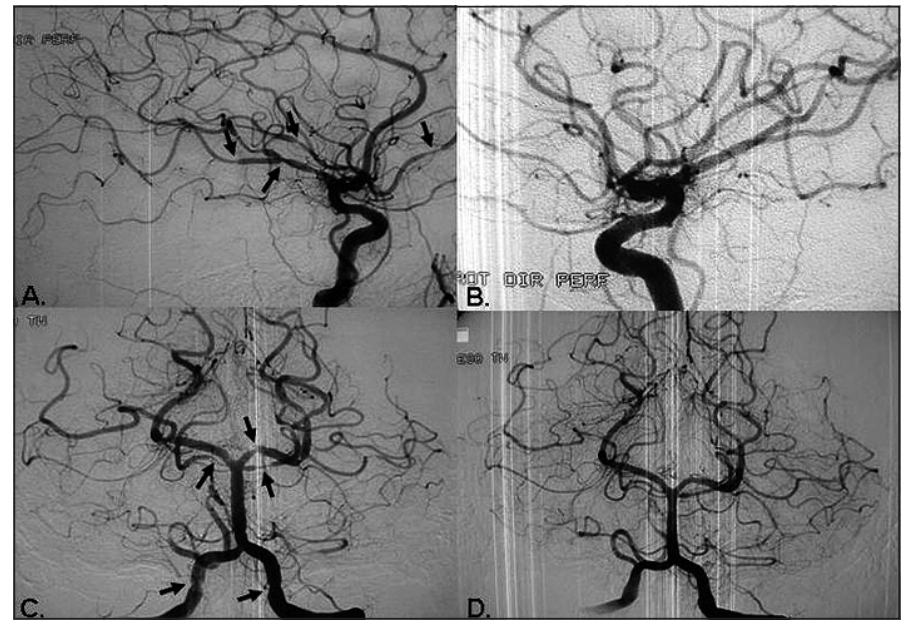

Figure 1. Digital angiographies performed on day 8 ( $A$ and $C$ ) and day 50 ( $B$ and $D$ ) after the start of the headache. The arrows show the arteries that present vasoconstriction. 


\section{Discussion}

Our patient presented a condition of $\mathrm{TCH}$ associated with sexual intercourse. Sexual intercourse may serve as a trigger for headache relating to RCVS ${ }^{6,8,17-21}$. This possibly occurs through sympathetic activation ${ }^{22}$.

The CSF presented a mild pleocytosis. Some authors have advocated that the leukocyte concentration in RCVS cases should be less than 10 cells/ $\mathrm{mm}^{3}$ and the protein concentration less than 80 $\mathrm{mg} / \mathrm{dL}^{4}$. In a large series, CSF abnormalities were found in $57 \%$ of the patients. The mean leukocyte concentration was 12 cells $/ \mathrm{mm}^{3}$ (range from 5 to 35). Increased red blood cells concentration was also found (mean of 1,569 cells $\left./ \mathrm{mm}^{3}\right)^{6}$. Our findings were compatible with that report.

One important differential diagnosis to be made is with primary angiitis of the central nervous system. In this condition headaches generally start insidiously ${ }^{4}$. The CSF generally reflects a condition of aseptic meningitis with modest pleocytosis and elevated protein levels (mean protein concentration of $177 \mathrm{mg} / \mathrm{dL}$ and mean leukocyte concentration of 77 cells $/ \mathrm{mm}^{3}{ }^{32}$. Although angiography shows that angiitis has a pattern similar to RCVS, its evolution over the course of time differs. The angiographic abnormalities may even stabilize or improve, but the condition does not revert ${ }^{24}$. Reversion of vasospasm within less than three months in our case confirmed the diagnosis of RCVS.

The inclusion of primary TCH in the IHS classification is based on evidence that patients with sudden headaches who present normal cranial CT scans and CSF analyses evolve well ${ }^{1,25,26}$. The other secondary causes, excepting subarachnoid hemorrhage, are generally rare.

Patients with vasospasm and TCH are classified as presenting secondary headache. Since some of these patients may have complications, it is necessary to differentiate them from cases of primary $\mathrm{TCH}$. This may be difficult in patients whose only symptom is headache and in whom there are no triggering factors having a recognized relationship with RCVS. The characteristics of the headache do not allow this differentiation, which is only done by demonstrating the existence of vasoconstriction through complementary tests ${ }^{8}$. These tests may initially present as normal ${ }^{6}$.

Headaches relating to RCVS generally recur within the first month after the first sudden headache, while primary TCH may continue to recur long after the first event $t^{6,8,25,26}$.

In $7 \%$ of the patients with RCVS, there is a previous history of headache associated with sexual activity ${ }^{6}$. In the case of our patient, our attention was drawn to the episode of sudden headache that occurred ten years earlier. Since there was no documentation regarding the presence of vasospasm, we cannot state that it was the same disease. On the other hand, we cannot neglect this possibility.

The question that arises from this is whether primary $\mathrm{TCH}$ exists or whether the cases classified as such are the ones without complications and in which the imaging examinations initially gave normal results.

We consider that studies evaluating the presence of vasospasm in cases of sudden headache unrelated to aneurysmatic SAH are needed. Such studies would need to take into account the fact that vasospasm may not occur immediately after the headache. Comparison between TCH patients with and without vasoconstriction could provide better clarification regarding whether these are really two different conditions.

In conclusion, reversible cerebral vasoconstriction syndrome is a secondary cause of headache that can be associated with neurological complications such as ischemic stroke, hemorrhagic stroke, cortical SAH, cerebral edema and arterial dissection. Patients who have thunderclap headache with normal brain CT and cerebrospinal fluid without xantochromia should be investigated for this syndrome.

\section{References}

1. Headache Classification Committee of the International Headache Society. The International Classification of Headache Disorders: 2nd edition. Cephalalgia 2004; 24 Suppl 1: 9-160.

2. Landtblom AM, Fridriksson S, Boivie J, Hillman J, Johansson G, Johansson I. Sudden onset headache: a prospective study of features, incidence and causes. Cephalalgia 2002; 22: 354-60.

3. Linn FH, Wijdicks EF, van der Graaf Y, Weerdesteyn-van Vliet FA, Bartelds AI, van Gijn J. Prospective study of sentinel headache in aneurysmal subarachnoid haemorrhage. Lancet 1994; 344 (8922): 590-3.

4. Calabrese LH, Dodick DW, Schwedt TJ, Singhal AB. 
Narrative review: reversible cerebral vasoconstriction syndromes. Ann Intern Med 2007; 146: 34-44.

5. Schwedt TJ, Matharu MS, Dodick DW. Thunderclap headache. Lancet Neurol 2006; 5: 621-31.

6. Ducros A, Boukobza M, Porcher R, Sarov M, Valade D, Bousser MG. The clinical and radiological spectrum of reversible cerebral vasoconstriction syndrome. A prospective series of 67 patients. Brain 2007; 130 (Pt 12): 3091-101.

7. Hajj-Ali RA, Furlan A, Abou-Chebel A, Calabrese LH. Benign angiopathy of the central nervous system: cohort of 16 patients with clinical course and long-term followup. Arthritis Rheum 2002; 47: 662-9.

8. Chen SP, Fuh JL, Lirng JF, Chang FC, Wang SJ. Recurrent primary thunderclap headache and benign CNS angiopathy: spectra of the same disorder? Neurology 2006; 67: 2164-9.

9. Singhal AB. Postpartum angiopathy with reversible posterior leukoencephalopathy. Arch Neurol 2004; 61: 411-6.

10. Geraghty JJ, Hoch DB, Robert ME, Vinters HV. Fatal puerperal cerebral vasospasm and stroke in a young woman. Neurology 1991; 41: 1145-7.

11. Singhal AB, Caviness VS, Begleiter AF, Mark EJ, Rordorf G, Koroshetz WJ. Cerebral vasoconstriction and stroke after use of serotonergic drugs. Neurology 2002; 58: 130 3.

12. Williams TL, Lukovits TG, Harris BT, Harker Rhodes C. A fatal case of postpartum cerebral angiopathy with literature review. Arch Gynecol Obstet 2007; 275: 67-77.

13. Lu SR, Liao YC, Fuh JL, Lirng JF, Wang SJ. Nimodipine for treatment of primary thunderclap headache. Neurology 2004; 62: 1414-6.

14. Sturm JW,Macdonell RA. Recurrent thunderclap headache associated with reversible intracerebral vasospasm causing stroke. Cephalalgia 2000; 20: 132-5.

15. Dodick DW, Eross EJ, Drazkowski JF, Ingall TJ. Thunderclap headache associated with reversible vasospasm and posterior leukoencephalopathy syndrome. Cephalalgia 2003; 23: 994-7.

16. Wang SJ, Fuh JL, Wu ZA, Chen SP, Lirng JF. Bath-related thunderclap headache: a study of 21 consecutive patients. Cephalalgia 2008; 28: 524-30.

17. Valenca MM, Valenca LP, Bordini CA, da Silva WF, Leite JP, Antunes-Rodrigues J, et al. Cerebral vasospasm and headache during sexual intercourse and masturbatory orgasms. Headache 2004; 44: 244-8.

18. Silbert PL, Hankey GJ, Prentice DA, Apsimon HT. Angiographically demonstrated arterial spasm in a case of benign sexual headache and benign exertional headache. Aust N Z J Med 1989; 19: 466-8.

19. Kapoor R, Kendall BE, Harrison MJ. Persistent segmental cerebral artery constrictions in coital cephalgia. J Neurol Neurosurg Psychiatry 1990; 53: 266-7.

20. Jackson M, Lennox G, Jaspan T, Jefferson D. Migraine angiitis precipitated by sex headache and leading to watershed infarction. Cephalalgia 1993; 13: 427-30.

21. Dodick DW, Brown RD, Jr., Britton JW, Huston J, 3rd. Nonaneurysmal thunderclap headache with diffuse, multifocal, segmental, and reversible vasospasm. Cephalalgia 1999; 19: 118-23.

22. Dodick DW. Reversible segmental cerebral vasoconstriction (Call-Fleming syndrome): the role of calcium antagonists. Cephalalgia 2003; 23: 163-5

23. Calabrese LH, Duna GF, Lie JT. Vasculitis in the central nervous system. Arthritis Rheum 1997; 40: 1189-201.

24. Alhalabi M,Moore PM. Serial angiography in isolated angiitis of the central nervous system. Neurology 1994; 44: 1221-6.

25. Wijdicks EF, Kerkhoff H, van Gijn J. Long-term followup of 71 patients with thunderclap headache mimicking subarachnoid haemorrhage. Lancet 1988; 2 (8602): 6870.

26. Markus HS. A prospective follow up of thunderclap headache mimicking subarachnoid haemorrhage. J Neurol Neurosurg Psychiatry 1991; 54: 1117-8. 